\title{
Ciência e saúde coletiva: da necessidade da razão crítica
}

Emprestando à epidemiologia o mote clássico das 'doenças em populações', e invertendo sua primeira parte para 'saúde das populações', pode-se dizer que essa expressão define, de um modo abrangente, todo o campo da saúde coletiva. Nas suas várias dimensões disciplinares, os dois termos dessa expressão estão contemplados de um modo ou de outro. Em sua origem histórica, no preventivismo clássico, esta relação era o fundamento de intervenções maciças sobre a sociedade, eventualmente com grau importante de eficácia, mesmo que de modo brutal. Ainda que matizada, esta vertente de intervenção está ainda hoje presente com maior ou menor intensidade de um modo difuso em nossa área, quer mais explicitamente, como no caso das atividades de planejamento e administração em saúde, quer mais indiretamente, no caso das recomendações derivadas dos estudos epidemiológicos.

Dito de outra forma, parte importante do conhecimento produzido ou utilizado neste campo tão complexo está a serviço de práticas normativas, o que traz invariavelmente a necessidade de um propósito ético como ideal regulador. A utilização acrítica do conhecimento técnico em intervenções nos coletivos humanos é um tema já bastante abordado, tanto nas discussões sobre o caráter tecnocrático de uma ou outra política governamental, quanto em um nível menor no exame das relações de poder entre especialistas e população, como, por exemplo, na já extensa literatura sobre o processo de medicalização social. O fato de a produção sobre este tema ser extensa não quer dizer, contudo, que se esteja atentando devidamente para as suas implicações.

Uma linha de investigação nesse sentido, com projetos em vários centros de pesquisa em nosso país, é a das várias abordagens sobre o processo de produção e validação do conhecimento científico. Esta abordagem é estratégica por ser este tipo de saber o que determina o sentido e a lógica das intervenções sobre o socius nos moldes criticados. Nas palavras de um desses pesquisadores, "está mais do que na hora de recuperar uma característica central do iluminismo: a crítica, mesmo se, como severá, o seu exercício devesse hoje denunciar a unilateralidade do iluminismo e da civilização forjada pela modernidade."1

Os danos causados por essa lógica, que supõe uma razão onipotente, ao mesmo tempo perscrutadora de tudo e a salvo de qualquer inquirição, são bastante evidentes, por exemplo, nas conseqüências sociais e políticas do primado das idéias neoliberais na gestão da economia em diversos países da América Latina. Menos óbvios, mas nem por isso menos importantes, são os impactos contínuos da tradução não mediada do conhecimento produzido em condições controladas no laboratório para o cotidiano das populações.

Tome-se como exemplo as primeiras afirmações feitas sobre a AIDS no início da década de 80. A divulgação da expressão 'grupo de risco' e os conceitos a esta associados trouxeram o reforço de vel hos preconceitos e a falsa sensação de segurança para aqueles que não se identificaram com as categorias taxonômicas de então, com impactos negativos que se fazem sentir ainda hoje, mais de 15 anos depois.

Estas observações não têm como objetivo pôr em causa a utilidade do saber científico no enfrentamento dos desafios da saúde coletiva, mas demonstrar que, como propôs Boaventura de Souza Santos2: “(...) só aplicando a ciência contra a ciência épossível levá-la a dizer não só o que sabe desi, mas tudo aquil lo quetem de ignorar a seu respeito para poder saber da soci edade o que esperamos que ela saiba." Ainda segundo este autor: "A luta pela ciência pós-moderna e pela aplicação edificante do conhecimento científico é, si multaneamente, a luta por uma sociedade queas torne possíveis emaximizea sua vigência."2

\footnotetext{
Kenneth Rochel de Camargo J $r$.

Instituto de Medicina Social, Universidade do Estado do Rio deJaneiro

1 Plastino, C. A., 1996. Os horizontes de Prometeu. Physis, 6:195-216.

2 Santos, B. S., 1988. Introdução a uma Ciência Pós-moderna. Rio de Janeiro: Editora Graal.
} 


\section{Science and collective health: on the need for critical reason}

By ascribing to Epidemiology its traditional reading as "diseases in populations" and switching the first part so as to read "the health of populations", one can say that the expression defines the entire field of Collective Health. The two terms in the expression are approached thematically one way or another in the field's various dimensions. At its historical origins, in classical preventive medicine, this relationship provided the groundwork for broad interventions in society, at times with a major degree of efficacy, even when the form was brutal. Although modified, this watershed of health interventions is still present to a greater or lesser extent, permeating our field, sometimes explicitly, as in Health Planning and Management activities, and other times more indirectly, as with recommendations based on epidemiological studies.

To put it another way, a relevant portion of the knowledge produced or used by this highly complex field is at the service of normative practices, invariably raising the need for an ethical purpose as a regulatory ideal. The uncritical utilization of technical knowledge in interventions involving human communities has been approached extensively, both in discussions on the technocratic nature of various government policies and at a more micro level in reviewing power relations between experts and the population, as in the extensive literature on the process of social medicalization. Still, the fact that research on this theme is so extensive does not, in itself, guarantee a sufficient focus on its implications.

A line of investigation in this direction, with projects in various Brazilian research centers, involves the various approaches to the process of production and validation of scientific knowledge. This line of investigation is strategic precisely because the type of knowledge determines the sense and logic of interventions into the socius in the form criticized. In the words of one such researcher, "The time has cometo recover a central characteristic of the Enlightenment: critique, even if, as we shall see, its exerci se today must denounce the one-sidedness of Enlightenment and the civilization forged by modernity". 1

The damage caused by this logic is evident, as it presupposes an omnipresent Reason that simultaneously scrutinizes everything and is itself exempt from any form of inquiry. One obvious example involves the social and political consequences of the primacy of neoliberal ideas in managing the economy of various Latin American nations. Less obvious, but no less important, is the continuous impact of the unmediated translation of knowledge produced under controlled laboratory conditions and applied directly to the population's daily living conditions.

A prime example is the first wave of statements concerning AIDS in the early 1980 s. Widespread use of the expression "risk group" and the concepts associated with it reinforced existing prejudices and gave a false feeling of security to those who did not identify with the taxonomic categories of the time, producing a negative impact still felt today, fifteen years later.

Such observations are not intended to question the usefulness of scientific knowledge in dealing with collective health challenges, rather, to demonstrate, as proposed by Boaventura de Souza Santos2, that “(...) only by applying science against science is it possible to lead science to say both that which it knows about itself and about everything that it must ignore about itself in order to know about society that which weexpect of it." To further quote this author, "The struggle for both post-modern science and the edifying application of scientific knowledge is at the same timethe struggle for a society that makes such science and its application possible, while maximizing their effect".2

Kenneth Rochel de Camargo Jr.

Instituto de Medicina Social, Universidade do Estado do Rio de Janeiro

1 Plastino, C. A., 1996. Os horizontes de Prometeu. Physis, 6:195-216

2 Santos, B. S., 1988. Introdução a uma Ciência Pós-moderna. Rio de Janeiro: Editora Graal. 